\title{
The 2020 US Presidential Election and the Transatlantic Relationship Under Stress
}

\author{
Lora Anne Viola
}

Published online: 27 October 2020

(C) The Author(s) 2020

\begin{abstract}
President Trump has created turmoil in the transatlantic relationship. Biden has taken a conciliatory tone towards allies and promised to return the US to multilateral cooperation as president. But the transatlantic relationship will never return to its heyday. Three long-term trends will shape the future of US foreign policy and the transatlantic relationship: the global shift in the distribution of power, and especially what the US-China rivalry means for Europe; the US' ambivalence towards multilateralism and why it will likely endure; and changing domestic coalitions within the US that might be a harbinger of a foreign policy revolution.
\end{abstract}

Keywords Transatlantic relationship · US foreign policy · Global power shift · NATO $\cdot$ Digital technology $\cdot$ Progressive foreign policy 


\section{Die US-Präsidentschaftswahlen 2020 und transatlantische Beziehungen unter Druck}

Zusammenfassung Präsident Trump sorgt für Unruhe in der transatlantischen Beziehung. Biden äußert sich gegenüber Verbündeten versöhnlich und will die USA als Präsident zur multilateralen Kooperation zurückführen. Doch die transatlantische Partnerschaft wird nie zu ihrer Blüte zurückkehren. Drei Trends werden künftig die US-Außenpolitik und die transatlantische Beziehung prägen: die globale Machtverteilung und die Frage, was die US-China-Rivalität für Europa bedeutet; die Ambivalenz der USA gegenüber Multilateralismus und warum dieser wohl bestehen wird; und die sich wandelnden Koalitionen innerhalb der USA, die Vorboten einer außenpolitischen Revolution sein könnten.

Schlüsselwörter Transatlantische Beziehung · US-Außenpolitik · Globale Machtverschiebung · NATO · Digitale Technologie · Progressive Außenpolitik

\section{Introduction}

Called the "Great Disruptor" by supporters, President Trump's rhetoric and decisions have - true to label—challenged established norms of politics and contributed to political uncertainty (Hicks and Ellis 2018). This uncertainty has been keenly felt in foreign policy, and especially in the transatlantic relationship. From his disparagement of NATO, to his use of punitive tariffs to force concessions, to his contempt for multilateralism, to his willingness to court dictators, Trump's foreign policy appears to break the mold on long-standing US normative and strategic commitments. There is also no indication that a second term would temper Trump's foreign policy, as even norm-conforming presidents have historically faced fewer moderating constraints in their second term (Drezner 2012). In light of this, some have pinned their hopes on Joe Biden, arguing that the transatlantic relationship will improve and even be repaired once Trump is out of office (Soros 2020; Colson and Payne 2020); and to be sure, Biden has taken a conciliatory tone towards allies and has promised to return the US to multilateral cooperation should he become president (Biden 2020). But a change in presidency will not turn back the clock on the transatlantic relationship. Beyond the idiosyncrasies of President Trump, deeper changes are transforming the relationship.

Three long-term, inter-related, trends will be particularly influential in shaping the future course of US foreign policy and the transatlantic relationship: First, the global shift in the distribution of power, and especially the implications of the USChina rivalry for Europe; second, the US' enduring ambivalence towards multilateralism, which is likely to persist even with a president normatively committed to multilateralism; third, changing domestic coalitions within the US that are eroding the traditional foreign policy elite consensus and giving voice to new, progressive, views that might be a harbinger of a foreign policy revolution. All three trends will continue to put the transatlantic relationship under pressure, even if in different ways. 


\section{The Global Power Shift: Implications of the US-China Rivalry for Europe}

Both the transatlantic relationship and America's position in the world have been undergoing a slow transformation since the end of the Cold War. During the Cold War, the NATO alliance had a clear purpose shared by all members-to deter and defend against the Soviet Union. NATO found new purposes after the end of the Cold War, but there is still no stable consensus on what NATO ought to be doing and where it ought to be doing it (Moller 2020). In the meantime, since the mid2000's, US attention has shifted away from Europe as Asia has become the region most central to US strategic interests. The rise of China as an economic giant with political influence beyond its borders is now the US' main strategic concern. China has surpassed the US in share of world GDP, growing over the past 25 years from about $4 \%$ to over $19 \%$ today. ${ }^{1}$ Moreover, its pursuit of regional cooperation and geopolitical investment projects, such as the Belt and Road Initiative (BRI), enhances its ability to project political power.

The US-China rivalry is putting pressure on the transatlantic relationship in at least two ways. First, as US strategic interests shift away from Europe, its commitments to the region will naturally weaken, making the future of NATO precarious. Europe and NATO are by no means unimportant to the US-China relationship, but they are also not central to it. The US is turning attention instead to allies or potential allies in Asia, such as Australia, Japan, the Philippines, South Korea, and Thailand (Parameswaran 2019). Doubts about the US' level of commitment presents Europe with a dilemma. On the one hand, European states have a real interest in keeping the US' security guarantee through NATO because there is no other viable security plan on the table right now, and without the US, NATO would not be able to continue as it is (Herszenhorn 2019). As many US presidents, most vociferously Trump, have argued, this requires other member states to more seriously address the burden-sharing issue. For instance, while Germany's defense spending - a main target of Trump's vituperation-has risen recently, it still falls short of the NATO target (NATO 2019). Moreover, the current pandemic crisis will likely make defense spending a lower priority in many European capitals. On the other hand, the prospect of the US withdrawing or weakening its security commitments underscores the importance of the EU creating independent security and defense capabilities, including the industrial base required for production and procurement, research and development, and training and integration of military forces. This will require rethinking the consensus that integration on European defense should not interfere with NATO (e.g. the rule of no de-linking, no duplication, and no discrimination). ${ }^{2}$ Ironically, the US' security commitment to NATO, and the dependency that it creates, is at least part of the reason why it has been so difficult for European states to commit to the investments that European defense would need in the absence of NATO. Nevertheless, there is no question that, going forward, Europe will need to

\footnotetext{
1 The economic data is taken from IMF (2020).

2 The 3-Ds were set out by US Secretary of State Madeline Albright in remarks to the North Atlantic Council ministerial meeting in 1998 (as cited in U.S. Department of State 1998).
} 
think (even) more seriously about how it can reduce its dependence on the US and overcome the considerable obstacles to building its own defense capabilities-either through or outside of NATO.

The second consequence of the US-China rivalry for the transatlantic relationship is that Europe is increasingly squeezed between American and Chinese interests, putting it in a difficult position with thorny strategic choices ahead. Europe has close economic ties and interdependencies with both countries and, as Farrell and Newman have pointed out, these interdependencies can be weaponized for coercive ends (Farrell and Newman 2019). In particular, the US-China rivalry is shaping up to be a competition for political and economic dominance over global digital networks. Global supply chains and the dependence of trade in goods and services on digital infrastructures, have transformed logistics and communications networks into sites of political and economic competition. The US and China view these networks as powerful tools of leverage, data, surveillance, and even coercion. The US has been pressuring allies to reject Chinese providers of 5G networks, including an outright ban on Huawei. US Secretary of State Mike Pompeo and US Secretary of Defense Mark Esper both warned that European allies who do business with Huawei risk being shut out of intelligence cooperation with the US (Wintour 2020). China, meanwhile, threatened to retaliate against countries banning Huawei, whose expansion is central to its digital strategy. The BRI, China's regional infrastructure and development program intended to promote China's influence over a range of international economic flows, includes a Digital Silk Road initiative that will promote the export of Chinese technology and lock-in Chinese leadership through standardsetting and systems interoperability.

Clearly, decoupling from China or disentangling interdependencies are not viable options for either the US or Europe (Farrell and Newman 2020). But this fact only intensifies the political dilemma for European countries that depend on China's physical and digital products as well as on US provision of services and security. Importantly, the stakes are not confined to economic gains from trade, to technical issues, or even data privacy and network security alone, but entail long-term strategic and political consequences. Europe, caught in the middle, has thus far appeared undecided in how it wants to address these issues, variably seeing China as a partner, a competitor, and a rival. On some policy issues, however, Europe will be pressed to choose sides. This will be true regardless of who the next US president will be, as even Biden has said numerous times that he will be tough on China and he will expect Europe to be too (Wong et al. 2020).

\section{The US' Enduring Ambivalence towards Multilateralism}

Indeed, the global power shift is making international cooperation more complex in a number of ways, and this in turn has implications for the nature of multilateralism more broadly. Many commentators squarely blame Trump for undermining the liberal international order and withdrawing the US from global leadership. As Donald Tusk, then European Council President, put it during remarks at the 2018 G7 summit in Canada, "the rules-based international order is being challenged [...] 
by its main architect and guarantor, the US" (as cited in Buncombe 2018). Trump has not made a secret of his disdain for multilateral agreements or the international rule of law. He has withdrawn the US from the Paris Accord, the Iran Nuclear Deal, the Intermediate-Range Nuclear Forces (INF) Treaty, the UN Human Rights Council, and UNESCO. He has threatened to withdraw from the World Trade Organization (WTO) and from NATO, and he has announced his intent to withdraw from the World Health Organization (WHO). The White House has also sought to restrict or end funding for a number of UN programs. Trump's rejection of multilateralism has proven particularly challenging for transatlantic cooperation given the extent to which the transatlantic partnership has been embedded in and anchored by multilateral institutions.

Nevertheless, the US has a long history of ambivalence towards multilateralism that did not begin with Trump (Viola 2018). The very origins of American liberal internationalism began with Congress' refusal to join the League of Nations over concerns of compromising American sovereignty and being beholden to foreign political interests. Some of Trump's actions have precedent in the Reagan administration, which withdrew from UNESCO in 1984 and froze UN budgetary assessments to zero real-growth, making UN agencies increasingly dependent on voluntary contributions (Graham 2015). Threats to curb US funding for the UN, and even to end US membership, have continued to be features of the US' attempts to exert influence over multilateralism (Bond 2003). ${ }^{3}$ Moreover, compared to other advanced democracies, especially European countries, the US has often been a laggard in ratifying international agreements, including the International Criminal Court, the Kyoto Treaty, the Ottawa Landmines Convention, the Comprehensive Test Ban Treaty, the Convention on Biological Diversity, and the Convention on the Law of the Sea. The George W. Bush administration was characterized by similar debates over the end of multilateralism, with many voices criticizing the US' undermining of the liberal order (Kupchan and Trubowitz 2007). Arguably, even former President Barack Obama, who was rhetorically committed to multilateralism, failed to move US foreign policy in a decisively multilateral direction. The Obama administration had a few notable multilateral successes, but overall it emphasized diplomacy within ad hoc, informal groupings of states, such as on nuclear negotiations or on negotiations over trade in services, rather than within the traditional formal institutions associated with the liberal order (Skidmore 2012).

What explains US ambivalence towards multilateralism? A consideration of the historical pattern offers reasons to believe that the current trend could continue beyond Trump's presidency. Overall, US presidents have generally understood that multilateral institutions can be powerful instruments of foreign policy because of their ability to reduce transaction costs, promote compliance, and generate legitimacy. But the sovereignty costs of participating have proven acceptable only as long as the US has the power to set the terms of cooperation in alignment with its interests or exempt itself when institutional constraints become too costly. The US has always been skeptical about subordinating itself to rules and decisions that it did

\footnotetext{
3 Since congressman Ron Paul's first proposal of the American Sovereignty Restoration Act in 1997, there have been regular (although failed) attempts to get Congress to withdraw from the UN.
} 
not fully control and has always sought to preserve its ability to exclude itself from the rules. As a result, the US tends to be most willing to support multilateralism when its relative power is high, and more reluctant as its relative power declines.

During the Cold War and the immediate post-Cold War period, the costs of using large-scale multilateralism were relatively low for the US because of a broad alignment of interests between the US and countries in its sphere of influence. Even during this period, however, US support for inclusive multilateralism was contingent; the US expected major allies to defer to American leadership and interests. When goals and interests diverged, the US was able to use its hard and soft power resources to enforce convergence around its preferred outcomes.

But today, a number of rising powers with diverse preferences are becoming critical to global cooperation while the US' ability to dominate multilateral institutions has declined. As rising powers with preferences that diverge from US interests become more important for achieving cooperative outcomes, collective action and distributional problems intensify. The US's relative power decline, meanwhile, decreases its ability to deploy side-payments and inducements to overcome preference divergence and impose its own preferred outcomes. This has become clear with the deadlock at the WTO and with respect to the leverage that rising powers now have in trade negotiations, in climate agreements, and in security cooperation. This redistribution of power increases the likelihood that the benefits of multilateralism are outweighed by the costs of achieving alignment with the US's own preferences. This, in turn, produces incentives for the US to pursue its interests within a more selective, exclusive institutional setting where it can create a consensus among a group of like-minded states and, possibly, exert pressure on excluded states to make concessions (Viola 2020). The US uses minilateralism as a strategy for increasing its bargaining leverage and for circumventing the collective action and distributional problems of more inclusive multilateral negotiations.

Extrapolating this argument, then, we should expect US skepticism of large-scale multilateralism to continue as its leverage declines-no matter who is president. Even if it continues to support multilateralism, the US will likely face incentives to pursue its interests through minilateral or bilateral deals with like-minded states. Of course, the set of possible like-minded actors typically includes the EU and many European states because values and interests are still extensively shared across the Atlantic. Nevertheless, the form that multilateral cooperation takes is changing and the move away from large-scale multilateralism will re-shape the status quo institutional order (Viola 2020).

\section{Changing Domestic Coalitions: A Foreign Policy Revolution in the Making?}

Since the post-9/11 period, American foreign policy can be understood as a struggle to come to terms with the US' changing role in the world. Should the US throw its weight behind a reformed liberal international order that includes emerging players as equals? Should it retreat from its many global commitments and re-focus its resources on domestic issues and only selectively engage international ones? Should 
it pursue a neo-mercantilist nationalism? As yet, no clear consensus has emerged. The Obama administration's take was articulated through the pivot to Asia and the idea of leading from behind. Trump's vision of America's position in the world is captured under his slogan America First. Senator Bernie Sanders' campaign sought to introduce a progressive foreign policy into the Democratic platform, one that sees a much more limited leadership role for the US in global affairs. These diverse ideas express different approaches to coming to terms with the US' changing power position in the global structure and also changing domestic interests on foreign policy. Overall, even though the US public and elites still favor some form of internationalism, there is less consensus today on what that internationalism should look like in practice. The challenge is how to adjust to the new multipolar order in which US leverage is still powerful but declining, and in which domestic support for extensive foreign commitments is weakening. A new generation of foreign policy experts may have new answers.

The foreign policy elite in the US - what the former Deputy National Security Advisor Ben Rhodes famously called the "foreign policy blob" (as cited in Klion 2018) - have historically been committed to the idea that US leadership is necessary for world order and, for that reason, that US primacy needed to be maintained. This consensus cut across party lines and has faced very little intellectual challenge; it is the school that Biden and many Republicans of his generation belong to. But this consensus is starting to fragment-not only under the weight of Trump's America First politics, but also because of a generational change among liberals.

A new generation of foreign policy thinkers, practitioners and academics, has recently been formulating something called a "progressive foreign policy"- the foreign policy equivalent of what Sanders and Congresswomen Alexandria OcasioCortez (AOC) have introduced to domestic politics (Beinart 2018; Bessner 2018; Nexon 2018; Rapp-Hooper and Lissner 2018; Rapp-Hooper and Lissner 2019). Proponents of this "new international order" (Rapp-Hopper and Lissner 2018) are calling for US foreign policy to be harnessed to distinctly progressive goals rather than to (neo)-liberal policies and power primacy. Although the features of a progressive foreign policy are still being debated, some characteristics include: a rejection of neoliberalism and a less pro-trade and more pro-labor stance on economic issues; antimilitarism, including calls for a major reduction of defense spending and the end to military interventions; an emphasis on the importance of climate change; skepticism about the necessity of American primacy for global order and reluctance to project American power across the globe. Some voices advocate the view that it is time for a retrenchment of US global leadership. Sanders' foreign policy advisor Matt Duss, for example, has argued that US troop commitments to allies is unsustainable and needs to be re-thought (Friedman 2020). In other words, a truly progressive foreign policy would be a revolution in US foreign policy that springs from and completes a break from the post-Cold War consensus. It would also redefine the terms upon which the transatlantic partnership was created.

The progressive agenda is still being worked out, but the hope is "to transform Democratic foreign policy, much like neoconservatives in the 1980s and '90s did for the Republican Party, albeit in the opposite direction" (Wright 2020). Indeed, there is some evidence that progressive views are gaining influence. The 2020 Democratic 
Party Platform already reflects a move to the left on foreign policy and testifies to the pressure a mobilized progressive left is exerting within the party not only on domestic but also on foreign issues. ${ }^{4}$ If a progressive foreign policy agenda continues to make inroads into the establishment, it will surely have implications for the transatlantic relationship. On the one hand, it will mean a re-thinking of alliance commitments coming from a political position much closer to mainstream European politics in countries like Germany and France. Ironically, greater ideological compatibility between the US and some European countries might make difficult discussions about the future of security and defense cooperation more rather than less difficult. On the other hand, a progressive foreign policy agenda in the US might make new coalitions available for the transatlantic partnership; for example, more greenminded and neoliberal-critical cooperation partners on both sides might find it easier to achieve a new transatlantic trade agreement that finds consensus on environmental and regulatory standards.

For the moment, there are at least three distinct foreign policy visions jockeying for influence in the US: one is the traditional liberal internationalist position that has been the cornerstone of the foreign policy establishment and the basis of the transatlantic relationship, and which Biden still represents; another is Trump's version of nationalist retrenchment that has support among some conservative critics of the liberal international order; and the third is the progressive vision that is gaining sway among next generation foreign policy thinkers in the Democratic Party. Which of the three will predominate over the next few years is yet to be seen, but the fragmentation of foreign policy views itself indicates that Europe should not expect the US to easily and simply return to the kind of partner it has been in the past. We will continue to see volatility in US foreign policy as it negotiates its future position in the world.

\section{Conclusion}

Trump's presidency has challenged or overturned establishment views on foreign policy, and it has been particularly disruptive of the transatlantic relationship. In this regard, a change of leadership would likely bring some immediate relief, including the US' re-engagement with international partners at a time when the stakes of international cooperation are high. At the same time, however, the US' changing geopolitical position, especially vis-à-vis China, and weakening domestic support for US involvement abroad, will constrain any president's ability to return to the heyday of the transatlantic relationship. Aside from the fact that the next administration will be consumed with addressing urgent domestic issues, there is earnest discussion on both the left and the right about how the US should recalibrate its global role. What is clear, though, is that the transatlantic relationship remains in a period of transition that has not yet reached a new equilibrium state.

\footnotetext{
4 The party platform is available here: https://www.demconvention.com/wp-content/uploads/2020/07/ 2020-07-21-DRAFT-Democratic-Party-Platform.pdf. Accessed 21 Sep. 2020.
} 
Funding Open Access funding enabled and organized by Projekt DEAL.

Open Access This article is licensed under a Creative Commons Attribution 4.0 International License, which permits use, sharing, adaptation, distribution and reproduction in any medium or format, as long as you give appropriate credit to the original author(s) and the source, provide a link to the Creative Commons licence, and indicate if changes were made. The images or other third party material in this article are included in the article's Creative Commons licence, unless indicated otherwise in a credit line to the material. If material is not included in the article's Creative Commons licence and your intended use is not permitted by statutory regulation or exceeds the permitted use, you will need to obtain permission directly from the copyright holder. To view a copy of this licence, visit http://creativecommons.org/licenses/by/4. $0 \%$

\section{References}

Beinart, P. (2018, 16 Sep.). America needs an entirely new foreign policy for the Trump age. The Atlantic. https://www.theatlantic.com/ideas/archive/2018/09/shield-of-the-republic-a-democratic-foreignpolicy-for-the-trump-age/570010/. Accessed 21 Sep. 2020.

Bessner, D. (2018, 17 Sep.). What does Alexandria Ocasio-Cortez think about the South China Sea? The rising left needs more foreign policy. Here's how it can start. The New York Times. https://www. nytimes.com/2018/09/17/opinion/democratic-party-cortez-foreign-policy.html. Accessed 21 Sep. 2020.

Biden, J. (2020). Why America must lead again: Rescuing U.S. foreign policy after Trump. Foreign Affairs, March/April. https://www.foreignaffairs.com/articles/united-states/2020-01-23/why-americamust-lead-again. Accessed 21 Sep. 2020.

Bond, A. (2003). U.S. funding of the United Nations: Arrears payment as an indicator of multilateralism. Berkeley Journal of International Law, 21(3), 703-714.

Buncombe, A. (2018, 6 June). Trump is 'undermining' world order the US created, says top EU official in withering attack. The Independent. https://www.independent.co.uk/news/world/europe/trump-us-eug7-russia-donald-tusk-summit-canada-a8390426.html. Accessed 21 Sep. 2020.

Colson, T., \& Payne, A. (2020, 4 July). European diplomats believe Joe Biden will repair the damage done by Trump to America's broken alliance with Europe. Business Insider. https://www.businessinsider. com/europe-believes-biden-would-repair-trumps-damage-to-european-alliance-2020-7?r=DE\& IR=T. Accessed 21 Sep. 2020.

Drezner, D. (2012, 26 Mar.). The dirty little secret about second-term presidents. Foreign Policy. https://foreignpolicy.com/2012/03/26/the-dirty-little-secret-about-second-term-presidents/. Accessed 21 Sep. 2020.

Farrell, H., \& Newman, A. (2019). Weaponized interdependence: How global economic networks shape state coercion. International Security, 44(1), 42-79.

Farrell, H., \& Newman, A. (2020, 3 June). The folly of decoupling from China. Foreign Affairs. https:// www.foreignaffairs.com/articles/china/2020-06-03/folly-decoupling-china. Accessed 21 Sep. 2020.

Friedman, U. (2020, 11 Feb.). The Sanders Doctrine: The presidential candidate wants to redefine American power. The Atlantic. https://www.theatlantic.com/politics/archive/2020/02/bernie-sandersdoctrine-america-military-foreign-policy/606364/. Accessed 21 Sep. 2020.

Graham, E. (2015). Money and multilateralism: how funding rules constitute IO governance. International Theory, 7(1), 162-194.

Herszenhorn, D. (2019, 19 Apr.). Europe's NATO problem. Politico. https://www.politico.eu/article/ europe-nato-problem-defense-procurement-training-research/. Accessed 21 Sep. 2020.

Hicks, T., \& Ellis, C. (2018, 17 Oct.). Donald Trump: The Great Disruptor. The Hill. https://thehill.com/ opinion/white-house/411535-donald-trump-the-great-disruptor. Accessed 21 Sep. 2020.

IMF - International Monetary Fund (2020). World Economic Outlook. https://www.imf.org/external/ datamapper/PPPSH@WEO/OEMDC/ADVEC/WEOWORLD. Accessed 21 Sep. 2020.

Klion, D. (2018, 17 Oct.). Ben Rhodes and the crisis of liberal foreign policy. The Nation. https:// www.thenation.com/article/archive/ben-rhodes-and-the-crisis-of-liberal-foreign-policy/. Accessed 21 Sep. 2020.

Kupchan, C., \& Trubowitz, P. (2007). Dead Center: the demise of Liberal Internationalism in the United States. International Security, 32(2), 7-44. 
Moller, S. (2020). Twenty years after: assessing the consequences of enlargement for the NATO military alliance. International Politics, 57(1), 509-529.

NATO (2019). Defence Expenditures of NATO Countries (2013-2019). NATO Press Release, PR/CP(2019) 123. https://www.nato.int/nato_static_fl2014/assets/pdf/pdf_2019_11/20191129_pr-2019-123-en. pdf. Accessed 21 Sep. 2020.

Nexon, D. (2018, 4 Sep.). Toward a neo-progressive foreign policy: The case for an internationalist left. Foreign Affairs. https://www.foreignaffairs.com/articles/united-states/2018-09-04/toward-neoprogressive-foreign-policy. Accessed 21 Sep. 2020.

Parameswaran, P. (2019, 22 Nov.). Assessing US alliance management in Asia under the Trump administration. The Diplomat. https://thediplomat.com/2019/11/assessing-us-alliance-management-in-asiaunder-the-trump-administration/. Accessed 21 Sep. 2020.

Rapp-Hooper, M., \& Lissner, R. (2018). The day after Trump: American strategy for a new international order. The Washington Quarterly, 41(1), 7-25.

Rapp-Hooper, M., \& Lissner, R. (2019). The open world. What America can achieve after Trump. Foreign Affairs, May/June. https://www.foreignaffairs.com/articles/2019-04-16/open-world. Accessed 21 Sep. 2020.

Skidmore, D. (2012). The Obama presidency and US foreign policy: where's the multilateralism. International Studies Perspectives, 13(1), 43-64.

Soros, A. (2020, 6 July). A Biden victory could reset transatlantic relations. European Council on Foreign Relations. https://www.ecfr.eu/article/commentary_a_biden_victory_could_reset_transatlantic_ relations. Accessed 21 Sep. 2020.

U.S. Department of State (1998, 8 Dec.). Secretary of State Madeleine K. Albright - Statement to the North Atlantic Council. https://1997-2001.state.gov/statements/1998/981208.html. Accessed 21 Sep. 2020.

Viola, L. (2018). Trump und das Ende des Multilateralismus - schon wieder? In P. Horst, P. Adorf \& F. Decker (Eds.), Die USA-eine scheiternde Demokratie? (pp. 271-290). Frankfurt: Campus.

Viola, L. (2020). U.S. Strategies of Institutional Adaptation in the Face of Hegemonic Decline. Global Policy, forthcoming. https://doi.org/10.1111/1758-5899.12856.

Wintour, P. (2020. 15 Feb.). US defence secretary warns Huawei 5G will put alliances at risk. The Guardian. https://www.theguardian.com/us-news/2020/feb/15/us-defence-secretary-warns-us-allian ces-at-risk-from-huawei-5g. Accessed 21 Sep. 2020.

Wong, E., Crowley, M., \& Swanson, A. (2020, 6 Sep.). Joe Biden's China journey. The New York Times. https://www.nytimes.com/2020/09/06/us/politics/biden-china.html. Accessed 21 Sep. 2020.

Wright, T. (2020, 18 Feb.). The real progressive-centrist divide on foreign policy. The Atlantic. https:// www.theatlantic.com/ideas/archive/2020/02/progressive-centrist-divide/606646/. Accessed 21 Sep. 2020. 